\title{
The 47th Liege Colloquium: marine environmental monitoring, modelling and prediction
}

\author{
Alexander Barth ${ }^{1} \mathbb{D}$. Yajing Yan $^{2} \cdot$ Lars Nerger $^{3} \cdot$ Jean-Marie Beckers $^{1}$
}

Received: 1 August 2017 / Accepted: 4 August 2017 / Published online: 17 August 2017

(c) Springer-Verlag GmbH Germany 2017

The 47th International Liege Colloquium was held on 4-8 May 2015 on the subject of Marine Environmental Monitoring, Modelling and Prediction. Nowadays, observational networks and ocean models have become a central asset in the management of the ocean environment. This topic was already addressed during the 36th edition of the International Liege Colloquium in 2004 (Desaubies et al. 2006) and it has become clear that models, data networks and products have matured significantly since 2004. The range of topics addressed by this colloquium is also reflected in the present collection. The first theme discussed during the colloquium was the monitoring of the ocean. The topical collection includes an example of in situ measurements for an ADCP and spacetime optimal interpolation of currents by Sentchev and Yaremchuk (2016) and remote sensing by Ciancia et al. (2016) where MODIS/AQUA level 2-derived chlorophylla data were used to determine the primary productivity

Responsible Editor: Jörg-Olaf Wolff

Alexander Barth

A.Barth@ulg.ac.be

1 GeoHydrodynamic and Environmental Research (GHER), University of Liege, Liege, Belgium

2 LISTIC, Université Savoie Mont-Blanc, Annecy-le-Vieux, France

3 Alfred Wegener Institute, Helmholtz Center for Polar and Marine Research, Bremerhaven, Germany generated by vertical mixing. Several contributions to the modelling session addressed issues around multiscale interactions. The topical collection includes works of a 2-way nested model of the Northern Current in the North Western Mediterranean Sea at a resolution of 1/192 degrees resolving submesoscale processes (Declerck et al. 2016). A barotropic unstructured mesh model of the Congo River (Bars et al. 2016) and a baroclinic model of the Turkish Strait System are also part of this collection (Sannino et al. 2017). Yáñez et al. (2016) provide an example of an ecosystem model using an artificial neural networks for landings of anchovy (Engraulis ringens), common sardine (Strangomera bentincki), and jack mackerel (Trachurus murphyi) in the context of the A2 climate change scenario.

The 2015 colloquium had a relatively strong focus on data assimilation. First, assimilation schemes and systems were discussed and presented during the colloquium, for instance the OpenDA assimilation system coupled with NEMO (van Velzen et al. 2016) and more theoretical work on the implicit definition of error covariance matrix (Chu et al. 2016) and local assimilation scheme with global constraints and conservation (Barth et al. 2016). The collection includes also several studies of data assimilation with realistic ocean models. The work of Verlaan and Sumihar (2016) discusses the impact of individual or group of observations on forecast accuracy improvement. Vandenbulcke et al. (2017) shows an example of asynchronous assimilation of HF radar data. A way to address biases, in particular for low resolution models, is given by Canter et al. (2017). An example of assimilation of temperature profiles with the ensemble Kalman filter in 3-dimensional model of the North Sea is presented in Ponsar et al. (2016). Pein et al. (2016) discusses how salinity measurements in the Ems Estuary affect the reconstruction of the salinity field. The article by Sepp Neves et al. (2016), evaluating the risk of oil 
spills using ensemble simulations, is a contribution from the operational oceanography and applications session.

In total, 127 participants jointed the Liege Colloquium for this memorable event. The following topical collection gives a good overview of the range of subjects addressed during this event.

Acknowledgments In the name of the Scientific Committee and of the Organizing Committee, we want to thank the European Geosciences Union (EGU), the Walloon Region, the University of Liege and the EU FP7 programme thought the project SANGOMA (grant FP7-671 SPACE-2011-1-CT-283580-SANGOMA) for their valuable support.

\section{References}

Bars YL, Vallaeys V, Deleersnijder É, Hanert E, Carrere L, Channelière C (2016) Unstructured-mesh modeling of the Congo river-to-sea continuum. Ocean Dyn 66(4):589-603. doi:10.1007/s10236-016-0939-x

Barth A, Yan Y, Alvera-Azcárate A, Beckers JM (2016) Local ensemble assimilation scheme with global constraints and conservation. Ocean Dyn 66(12):1651-1664. doi:10.1007/s10236-016-0999-y

Canter M, Barth A, Beckers JM (2017) Correcting circulation biases in a lower-resolution global general circulation model with data assimilation. Ocean Dyn 67(2):281-298. doi:10.1007/s10236-016-1022-3

Chu PC, Fan C, Margolina T (2016) Ocean spectral data assimilation without background error covariance matrix. Ocean Dyn 66(9):1143-1163. doi:10.1007/s10236-016-0971-x

Ciancia E, Magalhães Loureiro C, Mendonċa A, Coviello I, Di Polito C, Lacava T, Pergola N, Satriano V, Tramutoli V, Martins A (2016) On the potential of an RST-based analysis of the MODIS-derived chl-a product over Condor seamount and surrounding areas (Azores, NE Atlantic). Ocean Dyn 66(9):11651180. doi:10.1007/s10236-016-0972-9
Declerck A, Ourmières Y, Molcard A (2016) Assessment of the coastal dynamics in a nested zoom and feedback on the boundary current: the North-Western Mediterranean Sea case. Ocean Dyn 66(11):1529-1542. doi:10.1007/s10236-016-0985-4

Desaubies Y, Rixen M, Beckers JM (2006) 36th international Liège colloquium on ocean dynamics Liège, Belgium, 3-7 may, 2004: Marine environmental monitoring and prediction. J Mar Syst 65:1-2. doi:10.1016/j.jmarsys.2006.09.002

Pein JU, Grayek S, Schulz-Stellenfleth J, Stanev EV (2016) On the impact of salinity observations on state estimates in Ems Estuary. Ocean Dyn 66(2):243-262. doi:10.1007/s10236-015-0920-0

Ponsar S, Luyten P, Dulière V (2016) Data assimilation with the ensemble Kalman filter in a numerical model of the North Sea. Ocean Dyn 66(8):955-971. doi:10.1007/s10236-016-0968-5

Sannino G, Sözer A, Özsoy E (2017) A high-resolution modelling study of the Turkish Straits System. Ocean Dyn 67(3):397-432. doi:10.1007/s10236-017-1039-2

Sentchev A, Yaremchuk M (2016) Monitoring tidal currents with a towed ADCP system. Ocean Dyn 66(1):119-132. doi:10.1007/s10236-015-0913-z

Sepp Neves AA, Pinardi N, Martins F (2016) IT-OSRA: applying ensemble simulations to estimate the oil spill risk associated to operational and accidental oil spills. Ocean Dyn 66(8):939-954. doi:10.1007/s10236-016-0960-0

van Velzen N, Altaf MU, Verlaan M (2016) OpenDA-NEMO framework for ocean data assimilation. Ocean Dyn 66(5):691-702. doi:10.1007/s10236-016-0945-z

Vandenbulcke L, Beckers JM, Barth A (2017) Correction of inertial oscillations by assimilation of $\mathrm{HF}$ radar data in a model of the Ligurian Sea. Ocean Dyn 67(1):117-135. doi:10.1007/s10236-016-1012-5

Verlaan M, Sumihar J (2016) Observation impact analysis methods for storm surge forecasting systems. Ocean Dyn 66(2):221-241. doi:10.1007/s10236-015-0912-0

Yáñez E, Plaza F, Silva C, Sánchez F, Barbieri MÁ, Aranis A (2016) Pelagic resources landings in central-southern Chile under the A2 climate change scenarios. Ocean Dyn 66(10):1333-1351. doi:10.1007/s10236-016-0984-5 